\title{
YOUR RACE SOUNDS FAMILIAR?
}

\author{
BLACKFACE, CROSS-RACIAL/CROSS-GEN DER \\ DRAG AND THE YOUR FACE SOUNDS FAMILIAR \\ FRANCHISE (2013-) ON POST-YUGOSLAV \\ TELEVISION
}

Catherine Baker

University of Hull

catherine.baker@hull.ac.uk

\begin{abstract}
Your Face Sounds Familiar, a celebrity talent television format developed by the Dutch production company Endemol and first broadcast in Spain in 2011, has entertained audiences in more than forty countries with the sight of well-known professional musicians impersonating foreign and domestic stars through cross-gender drag and, on many national editions, cross-racial drag, with results that would widely be regarded as offensive blackface where this has already been extensively challenged as racist in public. In central/south-east Europe, however, blackface is sometimes justified by arguing that it cannot be a racist practice because these countries have not had the UK and USA's history of colonialism and racial oppression. Through a study of the Croatian edition Tvoje lice zvuči poznato (2014-), where until 2020 blackface had rarely been publicly challenged, this paper explores how far a critical race studies lens towards blackface can also be applied there.
\end{abstract}

Keywords: blackface, Croatia, celebrity, drag, formatting, gender, popular music, race, reality television

\section{Introduction}

Your Face Sounds Familiar (YFSF), a celebrity impersonation format owned by the Dutch producers Endemol, has entertained audiences in more than 40 countries since the Spanish broadcaster Antena 3 premiered it in 2011. This adaptation of a transnational reality television format to local television and popular music cultures routinely involves cross-gender impersonation but also, since it challenges national pop and entertainment celebrities to impersonate global stars, brings with it transnational remediations of race. Since global popular music throughout the 20th and 21 st centuries has depended so heavily on the music, voices and images of stars of African descent, conveying representations of Blackness around the world where audiences encounter them through their own localised understandings of race, each edition's producers must decide whether and how to incorporate cross-racial impersonation in their show, a decision that becomes even more fraught when very few national celebrities are Black. In Croatia, and many other European countries without large historic Black populations, impersonations or what the show calls 'transformations' routinely cross racial boundaries to an extent that would be understood as uncomfortable and racist 'blackface' in television markets where it is no longer a norm. 
YFSF, known in Croatia as Tvoje lice zvuči poznato (TLZP - a literal translation), seems surprisingly unexplored in studies of reality and entertainment television despite the complex and sometimes troubling questions it raises about how the embodied aesthetics of celebrity, race, gender and nationhood might create meaning and stimulate the enjoyment and togetherness among mass national audiences that prime-time evening entertainment television aims for. ${ }^{1} \mathrm{~A}$ Spanish study describes the format's features and the interculturality of its movement "from the local to the global and vice versa," briefly mentioning contestants' changes of "musical genre and gender" but not race. ${ }^{2}$ The cross-gender transformations on Hunan TV's Chinese edition (2012-14) are among Jing Jamie Zhao's examples of "contemporary Chinese queer televisuality" in the late 2000s and early 2010s, which contrasts their "often parodic" celebrity gender-crossings with potentially more non-normative, yet tightly-disciplined, personas of gender non-conforming contestants on non-celebrity talent shows. ${ }^{3}$ Often, however, it is just another example of a formatted celebrity/musical reality show in audience surveys. ${ }^{4}$ The linguistic and aesthetic translations involved in its localisation nevertheless put the cultural politics of "formatting," or the global resale and remaking of television programming formats which has characterised 21 st-century entertainment production, into the spotlight. ${ }^{5}$ Since frameworks of race themselves are, as Ella Shohat and Robert Stam argue, "in translation," filtering transnational tropes through local understandings of geopolitical and social hierarchies to produce each society's racial order, localising YFSF necessarily involves translations of race even if this is not consciously articulated. $^{6}$

Other reality TV genres, meanwhile, have already been more deeply interrogated as audiovisual texts that craft what Lisa Nakamura calls "spectacles of race," in intersection with gender and class, for white majority national audiences. ${ }^{7}$ The stigmatising representation of Roma families on reality TV shows in both western and central/south-east Europe between the early 2000s and mid-2010s, the peak years of European Union (EU) eastward enlargement, has frequently troubled scholars of Romani citizenship and representation in postsocialist Europe, including Annabel Tremlett, Anca Pusca, and Anikó Imre. ${ }^{8}$ The relationship between what Imre describes as "national celebrity" and "racial intimacy" in a talent show featuring established celebrities from racially-unmarked ethnonational majorities is different from that created in reality documentaries which turn participants from racialised minorities into celebrities, but still exists in a context where:

By virtue of being hybrid platforms with a globally shared blueprint formula available for local appropriation, reality formats have been argued to trigger a rearticulation of national identities worldwide [...] In the postsocialist region, this new and unexpected mirror of national self-recognition has produced a Janus-faced image: it has both confirmed and unraveled national narratives and self-definitions. ${ }^{9}$

The racial regimes of light-entertainment music television in Europe have also been studied, with more focus on the representation of minority performers than the intimacies with race which are also created by watching performers from the white national majority or white performers from abroad. Since the 1950s, at least until the digital present, television has been the chief conduit for performances, interviews and videos that have made the star images of musicians of African and Asian descent from North America, the UK and the Global South part of popular culture in continental Europe - just as televised representations of Black Americans in activism, music and sport made television "a site of racial knowledge, racial identification, and racial dislocation" in 1960s Britain. ${ }^{10}$ Popular music has typically also been among the first televisual domains where Afro-Europeans and other members of racialised minorities have been represented to national audiences as part of their nation, albeit within a racialised division of labour that casts it as "natural" for Black people and Roma to participate in music, entertainment and dance but not in roles involving reason or authority. ${ }^{11}$

Minority contestants' participation on European reality television, as Kaarina Nikunen argues for Finland, thus make it "a site where the definitions of the ordinary and the nation are being circulated, contested, and, at times, stretched." 12 With amateur contestants, at least, "global format, production aims, and audience participation together challenge and expand the concept of [a majority nationhood] with transnational 
dimensions of citizenship and cross-border engagements."13 Yet on celebrity talent shows, especially when all contestants belong to the nation's ethnonational and racial majority, the politics and aesthetics of nationhood, race and belonging skew more towards Nikunen's second observation that in locally-formatted reality programming a "persistent nationalism in forms of conflicts and racism [still] pushes through the global format"14 - as with the Roma reality "documentaries." The racial intimacy that TLZP and other YFSF localisations create, in markets where 'transformations' cross visible racial boundaries, is one where international Black stars are a cherished part of the national pop canon, but also one where blackface is normalised enough not to be questioned. The Croatian edition, like other central/south-east European editions using blackface, thus raises what is currently the most pressing question in critical studies of race in postsocialist Europe - how far can analytical concepts created in societies where colonialism and the enslavement of Africans left direct legacies be applied in countries which were "not colonised" or "did not have empires," where those legacies are more diffuse ${ }^{15}$

Blackface on European television itself still needs studying in transnational, not just national, contexts. For the UK, Christine Grandy has recently argued that blackface and minstrelsy on 1950s-70s television [most famously, but not only, on The Black and White Minstrel Show (1958-1978)] were regularly defended by white producers and audiences as "harmless and indeed wholesome" even as Black magazines and anti-racist campaigners lobbied against it. ${ }^{16}$ Blackface in Britain was itself a "transatlantic transference" from the US, articulating stereotypes of Black people as lazy, unintelligent and comical both through outright minstrelsy and by white actors "blacking up" to play Black and Asian characters on film. ${ }^{17}$ Grandy explains how white people could still perceive blackface as detached from race by turning to critical race scholarship including the work of Eduardo Bonilla-Silva, Robin Bernstein and Charles Mills, which explains how such disavowals both claim positions of "racial innocence" and displace responsibility for racism on to those who point it out. ${ }^{18}$ The show's cancellation in 1978 has led to a popular belief that British culture has become less racist by no longer using blackface on television (even though certain white comedians have still used it): when the Spice Girls appeared on a Dutch talk show in 1997 and were confronted with five actors in blackface playing the Christmas character Zwarte Piet, Mel B and her bandmates protested to the host Paul de Leeuw, who was insisting it was Dutch "tradition" and "culture," "This is the nineties... update your culture!"19 I too was socialised into this perception as a young person in 1990s/2000s Britain.

Zwarte Piet, Sinterklaas's servant in Dutch Advent celebrations, is the most controversial of the carnival characters around whom contentions around blackface elsewhere in Europe mostly seem to turn (others include King Balthazar in Spain's Día de los Reyes parades and the less questioned "morčić" at Carnival in the Croatian city of Rijeka), and as in the De Leeuw example appears on television as well as in person. ${ }^{20}$ Drawing on Saidiya Hartman's work to question what this character might mean to white Dutch audiences, the Black Dutch feminist Gloria Wekker concludes his figure persuades the public of the natural "happiness" of Black people under white domination, imputes a "childishness" and "primitiveness" to Black people while marking it as improper for white citizens of the metropole, and in children's consciousness "sketches [...] the contours of how and what a black person is." ${ }^{21}$ Resistance to anti-racist campaigns against Zwarte Piet, expressed by defending him as harmless fun and disavowing any history of racism in Dutch national consciousness, epitomises the distancing strategy Wekker calls "white innocence", an innocence of white majoritarian entitlement which "is not as innocent as it appears to be."22 


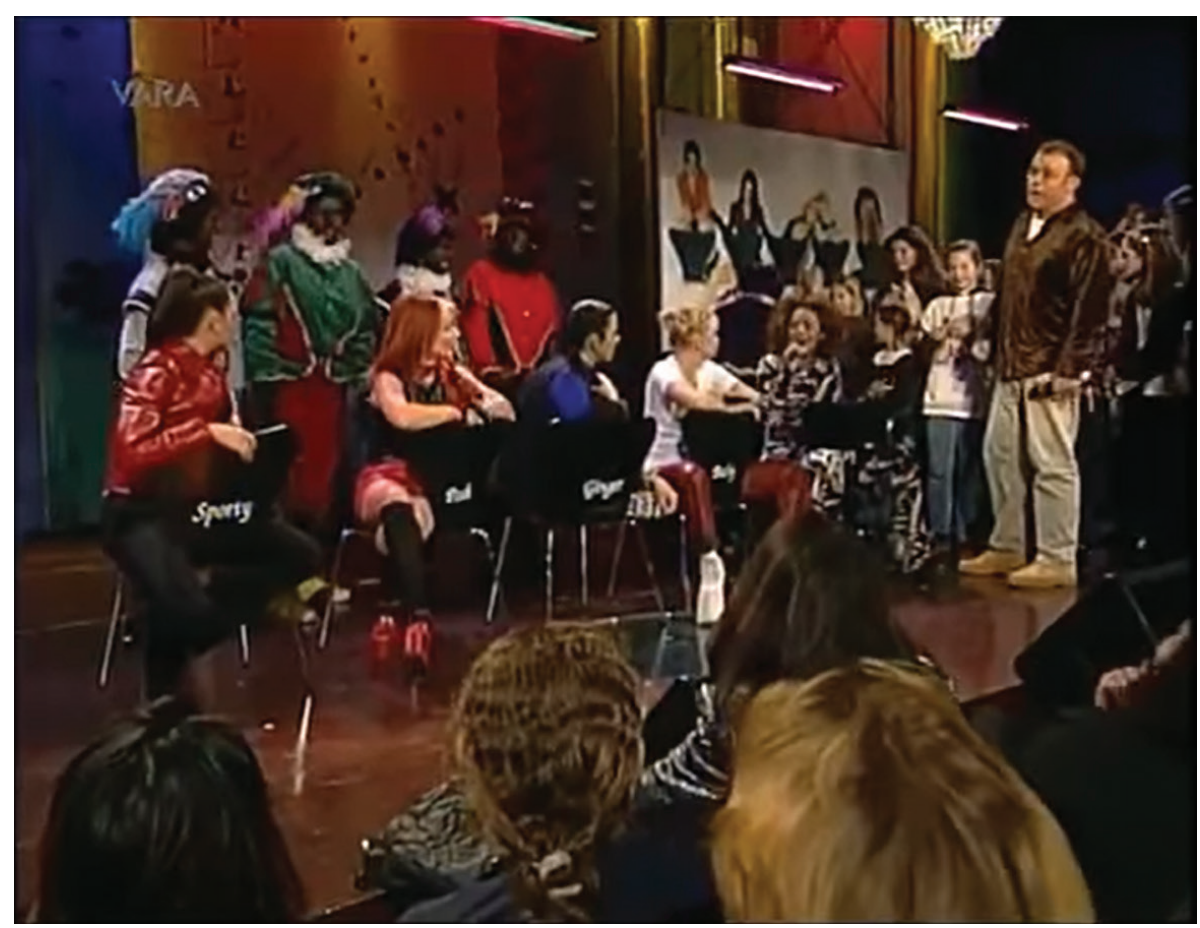

Video 1. The Spice Girls and Zwarte Piet, 1997.

Outside North American and UK contexts, reckoning with blackface can still leave (white) scholars uneasy about whether it is "fair" to call the practice as racist as it would commonsensically be there: are we, Catherine Cole asks, at risk of committing "interpretive imperialism" by making "American referents [...] the most important or salient" around the globe ${ }^{23}$ Jill Lane, considering a Spanish advertisement for Magnum ice-cream where the actor Paz Vega appeared in dark brown make-up to depict being overcome by passion for chocolate, attempts to theorise whether her shock as a white American woman seeing this image on Spanish city streets was, as her Spanish colleagues suggested, "simply a mistranslation, an imposition of a foreign racial logic on an unrelated scene."24 Following Michael Omi and Howard Winant's understanding of how racial "formations" invest race and its embodied signifiers with meaning in the US, Lane acknowledges that “'racialization' - the extension of racial meaning to particular relations, practices (like blackface), persons, or objects (like chocolate) - is a culturally and historically specific ideological process," which "means something different in Spain than it does in the United States" because these nations' histories are not the same. ${ }^{25}$ Winant's own later work on the "world racial system" allows her to affirm, nevertheless, that Spain as well as the US "participated [...] in the long history of conquest, slavery, and empire from which modern nation-states and more contemporary discourses of race emerged," including the material and then symbolic association between chocolate and Africa. ${ }^{26}$ With that history in mind, blackface can indeed be seen to have a racial referent in Spain, and in the Netherlands - the two countries from which YFSF came.

Lane's thinking through this spectatorial encounter between racial formations through the lens of "translation" echoes how that concept (through Shohat and Stam's work) has helped me account for localisations and contradictions of "race" in the post-Yugoslav region. ${ }^{27}$ It also points directly to the further problem of comparison when central and south-east Europe are concerned: how to make sense of apparently racialised representations in the media and visual cultures of European nations which did not have, like Spain, the USA or the UK, their "own colonial past of slavery,"28 and indeed were under other empires' domination when that exercise of colonial violence overseas was taking place? The impersonation of stars of African descent on a Croatian talent show developed from a Spanish format and also viewed online by a small, unintended international audience represents a complex set of translations of racialised gazes. Turning a critical race approach towards these gazes, and simultaneously retaining awareness that Croatia 
is not the UK or USA, creates a moment of what Imre, Katarzyna Marciniak, and Áine O'Healy call "transnational incommensurability" - when both these stances are realities that must be reconciled in order to work across difference. ${ }^{29}$ Does blackface on post-Yugoslav television mean what blackface would mean on television in the UK, or is it a mistranslation - even a colonising one - to suggest it is the product of a racialised history? To work through these contradictions, this paper explores how integral cross-racial impersonation is to $T L Z P$, offers a reading through my own subjectivity as a viewer, and explores critical responses to it in Croatia, where TLZP's blackface performances sparked little public debate until autumn 2020 in the global aftermath of the murder of George Floyd.

\section{Troje lice zvući poznato: Your Face Sounds Familiar on Post-Yugoslav Television}

Versions of Your Face Sounds Familiar have been developed for 27 different national television markets in Europe since the first Spanish series in 2011, mostly beginning in 2013 or 2014. In 2013 the Belgrade-based production company Emotion Production licensed the franchise from Endemol Shine and developed a version for Serbia's TV Prva which is also shown in Bosnia-Herzegovina $(\mathrm{BiH})$ and North Macedonia. ${ }^{30}$ This version of TLZP first aired in October 2013. Its success likely strengthened the interest of the Croatian broadcaster Nova TV, which launched its own version, produced with Emotion, in October 2014 under the same title, allowing most of its 'local' content to reflect Croatian rather than pan-Yugoslav musical memory. ${ }^{31}$ This airs in the prime light-entertainment slot of Sunday 8pm. Both editions have run annually since, except when Croatian TLZP would have clashed with the 2019 presidential elections; Season 6, beginning on March 8, 2020, was interrupted first by the Zagreb earthquake then by Covid-19, so only resumed with 6: 3 on September 27. The Slovenian version, Znan obraz ima svoj glas ( $A$ Well-Known Face Has Its Own Voice), first aired on POP TV in March 2014 but appears not to have been renewed since 2019.

These and all other editions of YFSF are localised for national audiences by combining impersonations of international stars (some of which at least recur between different national versions, with the same choreography and costumes) with impersonations of stars from national popular music culture, who are attributed the same iconicity. ${ }^{32}$ The boundaries of 'national' musical and televisual culture are blurred in the post-Yugoslav region, where popular music from the Yugoslav era can be claimed as everyday cultural memory in all the successor states but has also been subject to attempts in Croatia and Slovenia to distance national cultural heritage from the Yugoslav past, especially in Croatia with regard to Serbian performers and language: this cultural boundary was most heavily enforced during the Croatian war of independence ('Homeland War') once Croatian villages had started to be attacked by Serb paramilitaries and the Yugoslav People's Army (JNA), but has softened somewhat since. ${ }^{33}$ New music and television from other successor states still circulates in a common regional cultural space (more distant than 'domestic,' but closer than 'foreign'), albeit with the asymmetry that Croatian language is much more welcome on Serbian screens and airwaves than vice versa. By 2013-14, both commercial and public broadcasters had been saturating this space with commercialised reality television formats for a decade, mobilising what Zala Volčič and Mark Andrejevic described as a "commercial nationalism" that harnessed "the affective appeal of national identification, prejudices and stereotypes to sell." 34

Croatian TLZP upholds this observation in the proportions of Croatian, regional and international impersonations it contains. As of November 2020, it had featured 204 impersonations of US singers, 180 Croatian, 54 from the UK, and 35 from other Yugoslav successor states (mostly $\mathrm{BiH}$ ): other well-represented countries of origin were Italy (10), Germany, Spain, Puerto Rico (9), Sweden (8), Australia (7), Colombia, Canada (6), Barbados (5 - all Rihanna) and Jamaica (11, the fifth most popular country of origin if other Yugoslav successor states are combined into one figure). The imagination of 'the global' behind this pattern follows the contours of the contemporary global pop industry rather than, for instance, reflecting any strong presence of socialist Yugoslavia's former Non-Aligned partners in the Global South, another echo of how deeply these connections have been forgotten since late Yugoslav times. ${ }^{35}$ 
The range of contestants in each TLZP season stretches across genders, ages and (male) body shapes, the three main axes of bodily difference besides race that become salient in the 'transformations': most are professional singers of 'zabavna glazba' (light-entertainment music) or actors with some musical training, a few men have been rappers, and some contestants are best known as presenters or comedians (including Marina Orsag in the 2020 series, the show's first openly LGBTQ participant). The singers' participation on this and other celebrity talent shows is indicative of an economy where mid-list singers lack the earning opportunities their 1990s equivalents had through televised pop festivals and broadcast airplay of videos; today they are more likely to sing other people's songs than their own on TV. The 'transformations,' allocated using a weekly 'Randomiser,' are packages consisting of a film about the transformation, the performance itself, and comments and scores from the celebrity judges; the weekly winner donates a sum of money to their chosen charity, giving the show a humanitarian character.

Performing on TLZP is a vocally and physically demanding endeavour that lasts at least 12 weeks, confronts contestants with styles of singing and dancing they have not specialised in, and often requires singing live through facial prosthetics and/or tiring choreography: indeed, the struggles of older and less fit contestants to keep up with contemporary pop/R\&B dance routines give the show one of its common comic elements (similarly to celebrity ballroom and ice-dance franchises), not least when heavy-set older men are wearing feminine drag. All contestants have facial casts taken for prosthetics before the season begins, and sometimes participation involves extra bodily commitments for the duration of filming (men who usually wear facial hair go clean-shaven; women have to remove acrylic nails). ${ }^{36}$ Up to 1 November 2020, roughly half of Croatian TLZP's 568 performances involved cross-gender impersonation (48.9\%), slightly more in S4 and the incomplete S6 (55.7\% and $59.4 \%$ respectively), and women were slightly more likely to sing as men than vice versa, though not to any great degree (Table 1). Just over a quarter of performances (25.7\%) involved impersonating musicians who are racialised as non-white in a Croatian context, rising to just over a third in Seasons 5 and (so far) 6, while 11.8\% of performances involved both cross-gender and cross-racial drag.

Wearing dark make-up to impersonate musicians of African and Asian descent is only one element in the panoply of performance and impersonation practices that constitute TLZP's cross-gender and cross-racial drag. Here I use 'drag' similarly to Katrin Sieg describing white Germans' practices of cross-racial and cross-ethnic impersonation and masquerade as "ethnic drag": crossings of racial boundaries that operate as "a symbolic contact zone between German bodies and other cultures" as those white German bodies perform them. ${ }^{38}$ (Sieg has also explored how European television, specifically the Eurovision Song Contest, becomes a venue for staging certain "regimes of race" on a European scale; 39 TLZP's regimes of race are staged for national audiences, albeit through a transnationallymarketed format.) Rather than enacting the emancipatory "disidentifications" with which José Esteban Muñoz argued radical drag could "subvert the social fabric" through "creating an uneasiness in desire," 40 TLZP's parodic drag, performed by celebrities who until Orsag's series were all known to the public as heterosexual, is the kind that works to reinscribe "ideals of petite, sexualized femininity and tough masculinity" by making it "inherently funny when a large man puts on feminine stockings," or indeed when a petite woman thrusts her pelvis in masculine dress. ${ }^{41}$ This, at least, is the work it does for gender - but what does it do for race?

Table 1. Cross-gender and cross-racial impersonations on Croatian Tvoje lice zvuči poznato. ${ }^{37}$

\begin{tabular}{|c|c|c|c|c|c|c|c|c|}
\hline \multirow[t]{2}{*}{ Year } & \multirow[t]{2}{*}{ Performances } & \multicolumn{3}{|c|}{ Cross-gender } & \multirow[t]{2}{*}{ Cross-racial } & \multicolumn{3}{|c|}{ Cross-racial and cross-gender } \\
\hline & & $M$ to $F$ & $\mathrm{~F}$ to $\mathrm{M}$ & Total & & $M$ to $F$ & $\mathrm{~F}$ to $\mathrm{M}$ & Total \\
\hline 2014 (S1) & 96 & $15(15.6 \%)$ & $22(22.9 \%)$ & $37(38.5 \%)$ & $17(17.7 \%)$ & $3(3.1 \%)$ & $4(4.2 \%)$ & $7(7.3 \%)$ \\
\hline 2015 (S2) & 96 & $24(25.0 \%)$ & $21(21.9 \%)$ & $45(46.9 \%)$ & $24(25.0 \%)$ & $5(5.2 \%)$ & $5(5.2 \%)$ & $10(10.4 \%)$ \\
\hline 2016 (S3) & 104 & $24(23.1 \%)$ & $25(24.0 \%)$ & $49(47.1 \%)$ & $22(21.2 \%)$ & $5(4.8 \%)$ & $5(4.8 \%)$ & $10(9.6 \%)$ \\
\hline 2017 (S4) & 104 & $28(26.9 \%)$ & $30(28.8 \%)$ & $58(55.7 \%)$ & $24(23.1 \%)$ & $3(2.9 \%)$ & $7(6.7 \%)$ & $10(9.6 \%)$ \\
\hline 2018 (S5) & 104 & $25(24.0 \%)$ & $26(25.0 \%)$ & $51(49.0 \%)$ & $36(34.6 \%)$ & $9(8.7 \%)$ & $10(9.6 \%)$ & $19(18.3 \%)$ \\
\hline 2020 (S6) & 64 (to 1 Nov 2020) & $17(26.6 \%)$ & $21(32.9 \%)$ & $38(59.4 \%)$ & $23(35.9 \%)$ & $5(7.8 \%)$ & $6(9.3 \%)$ & $11(17.2 \%)$ \\
\hline Total & 568 & $133(23.4 \%)$ & $145(25.5 \%)$ & $278(48.9 \%)$ & $146(25.7 \%)$ & $30(5.3 \%)$ & $37(6.5 \%)$ & $67(11.8 \%)$ \\
\hline
\end{tabular}


Most, though not all, Croatian TLZP contestants will have been assigned at least one cross-racial performance during their season, including all contestants in 2015, 2017 and 2018 (Table 2). They are not distributed evenly through the season, so some episodes contain cross-racial performances and others have none; the 2018 season set a new record for the number of cross-racial performances and yet had none in its final. All episodes in contrast contain at least one cross-gender impersonation, suggesting that crossing gender boundaries is seen as constitutive of a TLZP episode in a way that crossing racial boundaries is not. Rather, changes of skin colour seem to be treated as incidentally as changes of age if that is necessary to approximate the original star's appearance. I count as 'crossracial' for this purpose any performance impersonating a singer who is of African, South or East Asian descent, or Roma (a people racialised in the region, and across Europe, as non-white); this includes singers of Afro-Latinx descent like Ozuna and Célia Cruz, but not white-presenting Latinx singers such as Ricky Martin, Luis Fonsi or Shakira, even though they too (especially Shakira) are often ascribed "a generalised 'other' ethnicity" in the racial order of Anglophone popular music, and in a study of how TLZP depicts Latinidad would deserve to be counted. ${ }^{42}$ Cross-racial impersonations of lighter-skinned stars may not be any darker than the heavy tan some national female celebrities presenting an 'ethnically ambiguous' appearance might wear anyway, though wig textures and facial prosthetics can push a performance's racialised appearance further towards the appearance of blackness; the deep brown skin tones in which contestants impersonate darker-skinned performers are unambiguously coded as black.

Table 2. Cross-racial impersonations by contestant. ${ }^{43}$

\begin{tabular}{|c|c|c|c|}
\hline Year & Contestant & Impersonations (episode) & Total \\
\hline \multirow[t]{7}{*}{2014 (S1) } & Mario Petreković (comedian) & $\begin{array}{l}\text { Beyoncé (e2) } \\
\text { Tina Turner (e5) } \\
\text { Lionel Richie (e9) } \\
\text { Bruno Mars (e12) }\end{array}$ & 4 \\
\hline & Baby Dooks (rapper) & $\begin{array}{l}\text { Psy (e3) } \\
\text { Esma Redžepova (e8) } \\
\text { James Brown (e9) } \\
\text { Nicolas Reyes (Gypsy Kings) (e10) } \\
\text { Andre } 3000 \text { (e11) }\end{array}$ & 5 \\
\hline & Minea (singer) & MC Hammer (e3) & 1 \\
\hline & Vanda Winter (singer) & $\begin{array}{l}\text { Stevie Wonder (e5) } \\
\text { Loreen (e7) } \\
\text { Loalwa Braz (Kaoma) (e10) } \\
\text { Rihanna (e12) }\end{array}$ & 4 \\
\hline & Jasna Palić-Picukarić (actor) & Pharrell Williams (e6) & 1 \\
\hline & Andrea Andrassy (actor) & Michael Jackson (e8) & 1 \\
\hline & Giuliano (singer) & Lenny Kravitz (e12) & 1 \\
\hline \multirow[t]{4}{*}{2015 (S2) } & Maja Šuput (singer) & $\begin{array}{l}\text { Bruno Mars (e1) } \\
\text { Šaban Bajramović (e4) } \\
\text { Donna Summer (e8) }\end{array}$ & 3 \\
\hline & Maja Posavec (actor) & $\begin{array}{l}\text { Jackson } 5(\mathrm{e} 2) \\
\text { Toni Braxton (e8) }\end{array}$ & 2 \\
\hline & Renata Sabljak (singer) & $\begin{array}{l}\text { Whitney Houston (e3) } \\
\text { Diana Ross (e6) } \\
\text { Prince (e8) } \\
\text { Cee Lo Green (e10) } \\
\text { Ruth Pointer (e12) }\end{array}$ & 5 \\
\hline & Ivan Šarić (comedian) & $\begin{array}{l}\text { Bob Marley (e3) } \\
\text { Grace Jones (e4) } \\
\text { Barry White (e7) } \\
\text { Michael Jackson (e9) } \\
\text { Nicki Minaj (e10) }\end{array}$ & 5 \\
\hline
\end{tabular}


Table 2. (Continued)

\begin{tabular}{|c|c|c|c|}
\hline Year & Contestant & Impersonations (episode) & Total \\
\hline & Ivana Marić (singer) & $\begin{array}{l}\text { Chaka Khan (e4) } \\
\text { Rihanna (e11) }\end{array}$ & 2 \\
\hline & Dušan Bućan (actor) & $\begin{array}{l}\text { Shaggy (e4) } \\
\text { Felly Kilingi (model, Technotronic 'Pump Up the } \\
\text { Jam' video) (e5) } \\
\text { Bobby Farrell (e8) } \\
\text { Cameo (e10) }\end{array}$ & 4 \\
\hline & Luka Bulić (actor) & Marvin Gaye (e10) & 1 \\
\hline & Saša Lozar (singer) & $\begin{array}{l}\text { Aretha Franklin (e11) } \\
\text { Beyoncé }(\mathrm{e} 12)\end{array}$ & 2 \\
\hline \multirow[t]{7}{*}{2016 (S3) } & Ana Maras Harmander (actor) & Gloria Gaynor (e1) & 1 \\
\hline & Filip Dizdar (singer) & $\begin{array}{l}\text { Will.i.am (e1) } \\
\text { Jason Derulo (e8) } \\
\text { Louis Armstrong (e11) }\end{array}$ & 3 \\
\hline & Lana Jurčević (singer) & $\begin{array}{l}\text { Bobby Farrell (e2) } \\
\text { Sean Paul (e6) } \\
\text { Beyoncé }(\mathrm{e} 12)\end{array}$ & 3 \\
\hline & Fil Tilen (rapper) & $\begin{array}{l}\text { King África (e2) } \\
\text { Redfoo (e6) } \\
\text { Alesha Dixon (e7) } \\
\text { Freedom Williams (e8) } \\
\text { Mary J Blige (e10) } \\
\text { Rick James (e13) }\end{array}$ & 6 \\
\hline & Damir Kedžo (singer) & $\begin{array}{l}\text { Tina Turner (e5) } \\
\text { The Weeknd (e9) } \\
\text { Maurice White (Earth, Wind and Fire) (e10) } \\
\text { Mariah Carey (e13) }\end{array}$ & 4 \\
\hline & Žanamari Perčić (singer) & $\begin{array}{l}\text { Prince (e8) } \\
\text { Victor Willis (Village People) (e10) } \\
\text { Bruno Mars (e12) }\end{array}$ & 3 \\
\hline & Matteo Cetinski (singer) & Martha Wash (e10) & 1 \\
\hline \multirow[t]{6}{*}{2017 (S4) } & Nives Celzijus (singer) & $\begin{array}{l}\text { Baha Men (e1) } \\
\text { Coolio (e6) }\end{array}$ & 2 \\
\hline & Mia Anočić-Valentić (actor) & $\begin{array}{l}\text { Chubby Checker (e1) } \\
\text { Césaria Évora (e7) } \\
\text { Michael Jackson (e11) } \\
\text { Sean Paul (e12) }\end{array}$ & 4 \\
\hline & Mario Roth (singer) & $\begin{array}{l}\text { Tina Turner }(\mathrm{e} 1) \\
\text { Don Omar (e2) } \\
\text { Gypsy Kings (e5) } \\
\text { James Brown (e12) }\end{array}$ & 4 \\
\hline & Ana Gruica (actor) & $\begin{array}{l}\text { Ray Charles (e2) } \\
\text { Salt'N'Pepa (e7) }\end{array}$ & 2 \\
\hline & Bojan Jambrošić (singer) & $\begin{array}{l}\text { OMI (e3) } \\
\text { Kool and the Gang (e6) } \\
\text { Prince (e9) } \\
\text { En Vogue (e11) }\end{array}$ & 4 \\
\hline & Ivana Mišerić (presenter) & $\begin{array}{l}\text { Ottawan (e4) } \\
\text { Michael Jackson (e7) } \\
\text { Rihanna (e9) }\end{array}$ & 3 \\
\hline
\end{tabular}


Table 2. (Continued)

\begin{tabular}{|c|c|c|c|}
\hline Year & Contestant & Impersonations (episode) & Total \\
\hline & Daniel Bilić (singer) & $\begin{array}{l}\text { Will Smith (e5) } \\
\text { Chuck Berry (e6) } \\
\text { Diana Ross (e10) }\end{array}$ & 3 \\
\hline & Dalibor Petko (presenter) & $\begin{array}{l}\text { Mory Kante (e6) } \\
\text { Inner Circle (e8) }\end{array}$ & 2 \\
\hline \multirow[t]{8}{*}{2018 (S5) } & Maja Bajamić (singer) & $\begin{array}{l}\text { Aretha Franklin (e1) } \\
\text { Labh Janjua (e2) } \\
\text { Carl Douglas (e4) } \\
\text { Beyoncé (e7) } \\
\text { Michael Jackson (e8) } \\
\text { John Legend (e10) }\end{array}$ & 6 \\
\hline & Damir Poljičak (actor) & $\begin{array}{l}\text { Amii Stewart (e1) } \\
\text { Mariah Carey (e4) }\end{array}$ & 2 \\
\hline & Matko Knešaurek (actor) & $\begin{array}{l}\text { Beyoncé (e1) } \\
\text { Mel B (e5) } \\
\text { Lionel Richie (e8) } \\
\text { Franky Gee (Captain Jack) (e10) } \\
\text { Melanie Thornton (La Bouche) (e12) }\end{array}$ & 5 \\
\hline & Paola Valić Bekić (singer) & $\begin{array}{l}\text { Tina Turner (e2) } \\
\text { Tionne Watkins (TLC) (e8) } \\
\text { Nicki Minaj (e10) } \\
\text { En Vogue (e11) }\end{array}$ & 4 \\
\hline & Ana Vilenica (actor) & $\begin{array}{l}\text { Kelis (e2) } \\
\text { Rockwell (e6) } \\
\text { Kool and the Gang (e9) } \\
\text { Stevie Wonder (e10) } \\
\text { Whitney Houston (e11) }\end{array}$ & 5 \\
\hline & Katarina Baban (actor) & $\begin{array}{l}\text { Jason Derulo (e3) } \\
\text { Rihanna (e6) } \\
\text { Prince (e7) } \\
\text { Bruno Mars (e10) } \\
\text { Kim Sasabone (Vengaboys) (e11) }\end{array}$ & 5 \\
\hline & Amel Ćurić (singer) & $\begin{array}{l}\text { Bobby Farrell (e3) } \\
\text { J Balvin (e5) } \\
\text { Celia Cruz (e9) } \\
\text { Barry White (e12) }\end{array}$ & 4 \\
\hline & Drele (comedian) & $\begin{array}{l}\text { Will Smith (e3) } \\
\text { Heather Small (e7) } \\
\text { Bob Marley (e9) } \\
\text { Esma Redžepova (e11) } \\
\text { Missy Elliott (e12) }\end{array}$ & 5 \\
\hline \multirow[t]{4}{*}{2020 (S6) } & Siniša Ružić (actor) & $\begin{array}{l}\text { Cardi B (e1) } \\
50 \text { Cent (e4) } \\
\text { The Temptations (e6) }\end{array}$ & 3 \\
\hline & Lana Klingor Mihić (singer) & $\begin{array}{l}\text { LunchMoney Lewis (e1) } \\
\text { Rihanna (e3) } \\
\text { Tina Turner (e6) } \\
\text { Pharrell Williams (e7) }\end{array}$ & 4 \\
\hline & Neda Parmać (singer) & $\begin{array}{l}\text { Daddy Yankee (e2) } \\
\text { Fleur East (e7) }\end{array}$ & 2 \\
\hline & Fabijan Pavao Medvešek (actor) & $\begin{array}{l}\text { Beyoncé, Jennifer Hudson (e2) } \\
\text { Lionel Richie, Diana Ross (e6) }\end{array}$ & 4 \\
\hline
\end{tabular}


Table 2. (Continued)

\begin{tabular}{lllc}
\hline Year & Contestant & Impersonations (episode) & Total \\
\hline & Lu Jakelić (singer) & Dr Alban (e2) & 3 \\
& Ciara, Missy Elliott (e3) & 2 \\
& Marina Orsag (singer) & Ozuna (e3) & 2 \\
& Barry White (e8) & Shaggy (e4) \\
& Sean Paul (e7) \\
\hline
\end{tabular}

When and how is it decided that editions of YFSF will contain blackface? In Spain - the site of Lane's meditations on blackface and cultural translation and the country where YFSF first aired - blackface was part of the show from the second episode, when Santiago Segura impersonated the blackness and blindness of Stevie Wonder to the point of being led on stage and (to audience laughter) fumbling with his keyboard's microphone. ${ }^{44}$ The same staging has since appeared in Croatia (Vanda Winter in 1: $5^{45}$ ), Slovenia (by Tomaž Ahačič, also in series $1^{46}$ ) and Greece, where the contestant, Mando, happened to have represented Greece at Eurovision in 2003. (Usually the impersonation uses "I Just Called To Say I Love You"; Mando sang "Part Time Lover.") Perhaps for this reason or perhaps due to greater overlap between the Greek and English-language social media spheres, Mando's clip caught the attention of several UK, Irish and US news websites, resulting in clickbait headlines such as "This Woman Blacked Up As Stevie Wonder in a TV Talent Show," "Greek Singer Sparks Outrage With Black Face Stevie Wonder Impersonation on Reality TV Show," and "Is This The Most Tasteless Talent Show Performance Ever?: Greek Pop Star 'Blacks Up' to Perform as Stevie Wonder" (this from the UK's Daily Mail, which readily enacts subtler forms of xenophobia ${ }^{47}$ ). ${ }^{48}$ The single UK and US seasons of YFSF had multi-racial casts of contestants, all staying within racial "lanes"; the 2012 Dutch edition, perhaps uniquely, may have taken cross-racial impersonation in both "directions," with the Black singer Edsilia Rombley seen wearing whiteface in the thumbnail for a (deleted) video of her impersonating Pink. ${ }^{49}$

The process by which reality show formats are franchised, marketed and localised gives glimpses into the points where decisions about blackface may or may not be made. Key actors in the process, as Ulrike Rohn describes for Estonia's adaptation of the Ido/ franchise, include the foreign format holder, the local production company and licensee, the local broadcaster (if different from the production company), and the "flying producer," a representative of the format holder who ensures consistent standards between countries. ${ }^{50}$ To determine whether or how cross-racial impersonation is negotiated or questioned when YFSF adaptations is produced would need knowledge of discussions between local partners and the flying producer, as well as insights into the local editions' production processes themselves. Interestingly, the blurb for YFSF in Endemol's 2012 catalogue for the MIPCOM trade show, quoted by Ann Fletchall, mentions age-crossing and gendercrossing but not cross-racial impersonation as part of its novelty and appeal: "Whether it's an older or younger person, or even someone of the opposite sex, it doesn't matter - vocal coaches, choreographers, make-up artists and stylists are ready to prep them for their big performance." 51 To openly refer to race might have made the format seem contentious in markets where blackface is sensitive, or might not even have seemed relevant to do. Even if franchise-holders do not acknowledge it, however, YFSFs cross-racial impersonations are still spectacles of race.

\section{TLZP's Race/Gender-crossing and the Spectatorial Gaze}

TLZP does not feature songs by Black singers in order to denigrate them. On the contrary, by their very inclusion, TLZP hails them as part of a pop canon in Croatia that has stood the test of time: beloved soul and disco hits, incorporated into a vibrantly-localised Yugoslav disco culture in their own time; ${ }^{52}$ summer club and dance hits by Caribbean, South American and Afro-European acts that could easily be heard in bars or on radio alongside the Croatian and "Balkan" hits their sounds have influenced; a very few rap songs that have crossed over into pop. The most commonly impersonated performers - Beyoncé and Michael Jackson (6 times each), Tina Turner and Rihanna 
(5), Bruno Mars and Prince (4), Lionel Richie, Diana Ross, Barry White, Sean Paul, and Bobby Farrell of Boney M (3) - are stars whose images circulate to define blackness globally, through whom blackness is globally consumed. Yet "consumption" is the operative term, since these very acts of tribute and appreciation are simultaneously a practice that Hartman links to the present and past dehumanisation of Black lives in an "economy of enjoyment" founded on white ownership of black bodies, where "the ascription of excess and enjoyment to the African effaces the violence perpetrated against the enslaved." 53

A critical reading of TLZP's cross-racial impersonations would have to account, moreover, for the role of incongruity and comedy in producing meaning when white contestants are impersonating musicians of African descent. The contestants who are most frequently assigned cross-racial impersonations seem to be either male comedians and rappers, or woman with high voices and slight stature (Maja Bajamić and Fil Tilen had 6 cross-racial impersonations each on their seasons; Baby Dooks, Ivan Šarić, Drele, Renata Sabljak, Matko Knešaurek, Ana Vilenica and Katarina Baban each had $5)$; that is, combinations where bodily discrepancies might have most comedic effect. Until at least spring 2020 , most TLZP performance videos were accessible on the show's YouTube channel, and embedded into news portal articles about them. By October 2020 the channel had been geoblocked outside Croatia - potentially in reaction to events discussed at the end of this paper - but traces of past performances remain in still images, trailers, and clips uploaded by third parties: for the sake of accessibility the following discussion of a cross-racial (and cross-gender) performance is based on one of these.

Lana Jurčević's impersonation of Bobby Farrell singing "Daddy Cool" in TLZP 3: 2 (October 2, 2016) is a common configuration of race- and gender-crossing for the format: a slim, relatively young female pop star performing as an assertively-sexualised man. ${ }^{54} \mathrm{~A}$ few seconds while her face and body is in shadow build audience anticipation about how the transformation will appear. Wearing dark brown make-up, a thick afro wig, a copy of Farrell's white suit, a shark's-tooth necklace and a chestpiece that allows her costume to simulate a bare, hairy chest, Jurčević struts towards the camera, which cuts away to three backing vocalists (also in blackface) representing the three Black women in Boney M. Gleeful whistling, and the judges' incredulous laughter, are mixed to stand out in the applause track, and the visual accompaniment to the introduction shows several seconds of the judges' reaction to her dancing before viewers are shown the dancing itself. Jurčević does not attempt the full speed or athleticism of Farrell's dancing, her movements often appear disjointed rather than flowing, and she sings in a deeper register than her normal voice with exaggerated facial gestures that Farrell does not make; a box in the lower left of the screen shows Farrell's original performance in comparison, drawing perhaps unintentional attention to the dullness of her make-up and the artificial texture of her wig. The most overtly sexualised moment of the video she is imitating, where Farrell removes his shirt and straddles the microphone stand, ${ }^{55}$ is sanitised by dispensing with the backing vocal and Jurčević keeping her jacket on. Judges gave Jurčević second place that week. But knowing that "clowning" is a characteristic of minstrelsy, ${ }^{56} \mathrm{I}$ am left with an impression between bemusement, embarrassment and horror; I am not a viewer who is meant to share the fun.

A full study of TLZP as a multimedia text would need to analyse not only entire programmes rather than digital extracts but also promotional trailers and publicity about the transformations on web portals, magazines and social media feeds associated with the show and its contestants - much more content than there has been space to cover here. We can still make some indicative remarks. In the racialised economy of desire of which bell hooks writes:

Whites seek the black body to confirm that it is the exotic supersexed flesh of their fantasies [...] the "hypermasculine black male sexuality" is feminized and tamed by a process of commodification that denies its agency and makes it serve the desires of others, especially white sexual lust. ${ }^{57}$

Images of Black male athletes, models, actors and musicians have infused Croatian media culture too with this process, not just through transnationally-circulating cultural products but also when producers of Croatian photoshoots, videos or advertisements choose to feature men of African descent in similar ways. Such racialised exoticism would even have influenced the decision of Boney M's white German producer, Frank Farian, to have his studio vocals fronted by a Black man, Farrell. 
C. Baker, Your Race Sounds Familiar?

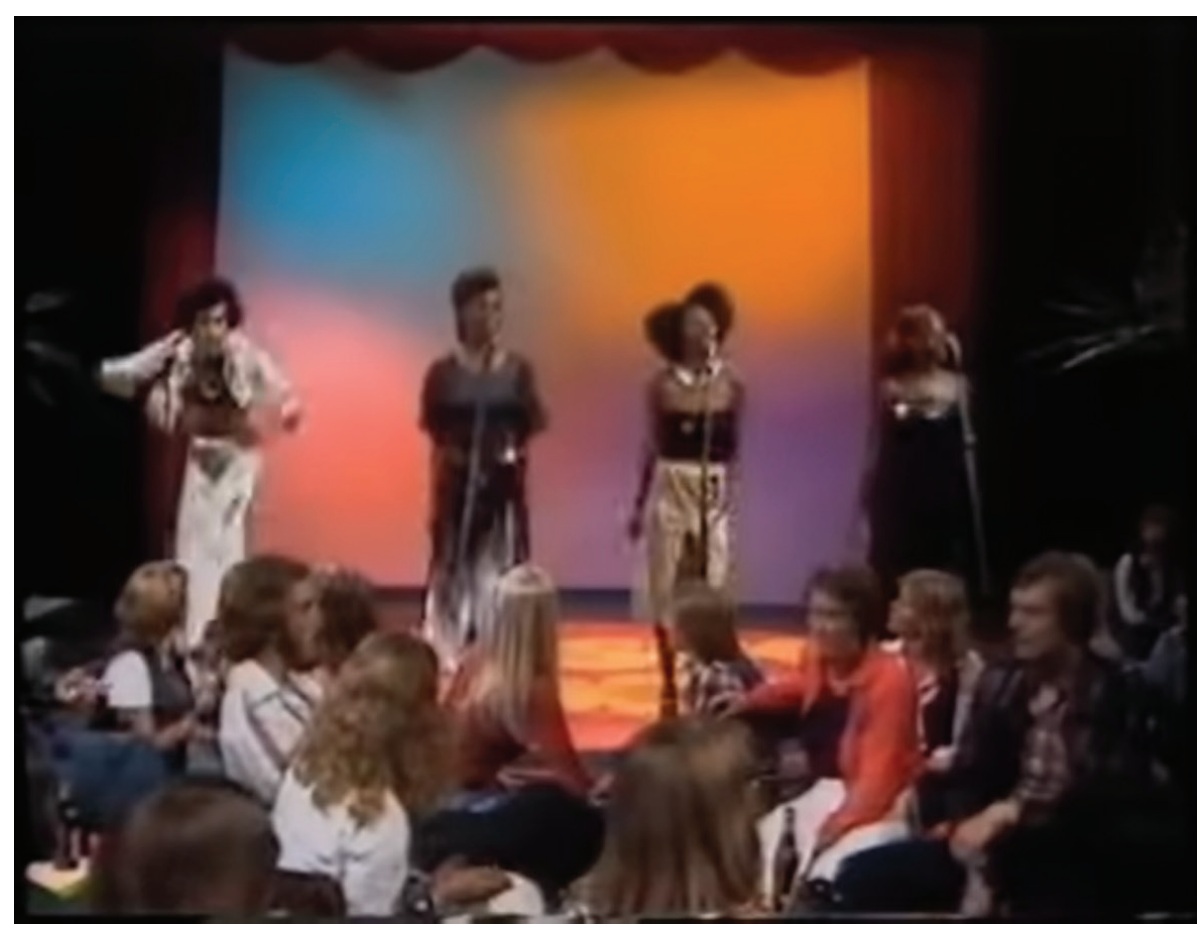

Video 2. Boney M, "Daddy Cool” (the video Jurčević appears to imitate).

Boney M's stardom, indeed, involved multi-layered transnational mediations of race, place and exoticism: a group of four Black Caribbean musicians working in West Germany, formed to embody and accompany their white producer's voice, whose musical identity blended Black disco 'cool,' Caribbean singing, and (on "Rasputin") the sound of an originally Sephardic, widely known as Turkish, folk song which has been claimed by multiple national folk traditions across south-east Europe and serves here to equate exoticism, easternness and Russia. ${ }^{58}$ The space of TLZP and the conventions of light-entertainment celebrity culture in Croatia (and elsewhere) do not invite the reflectiveness towards the politics and ethics of translating race, ethnicity, masculinity and femininity and performance that it is possible to elicit on, say, the drag king scene (where norms against overt blackface would be strong). ${ }^{59}$ Jurčević's performance as Farrell nevertheless depends both on how white audiences have learned to desire and fear Black masculinity in Croatia, and on how they expect a young white woman in light entertainment to behave when she embodies it. As Kathryn Rosenfeld observes:

While drag is by definition gender performed, it must also by extension be race performed, at least inasmuch as the stylistic and performative characteristics that compose "gender" operate analogously to those which, if they are not one and the same, compose "race."

This holds true not just for forms of drag which seek to critically expose the construction of race and gender through mobilising spectatorship, pleasure, laughter and desire but also for forms that reinforce it. Audiences' and judges' behaviour, as highlighted by TLZP's editors, generally draw viewers' attention to the idea that laughter and applause belong to moments where transgressions of gendered and racialised boundaries, as well as boundaries of age and body size, are most incongruous, not necessarily to virtuoso vocal and choreographic performances (much as the judges may reward these with their points). I feel almost sorry that Jurčević, who broke through in 2006-7 while I was researching my $\mathrm{PhD}$ and who I have always regarded as one of the most talented zabavna glazba singers of the mid-2000s, has to appear in my work for a performance which both plays against her strengths and involves a practice I have been socialised to regard as offensive; though that matters less than the affective reactions of viewers from racialised minorities in Croatia encountering this performance or its digital aftertraces, including some who might have been fans of hers as well. ${ }^{61}$ 
Indeed, as a viewer and scholar who has been familiar with some TLZP contestants and their music for more than half my life (I started following Croatia's "Dora" preselection for Eurovision in 1999, and both Minea and Renata Sabljak competed that year), I find TLZP's cross-racial performances almost unwatchable. The aversion is deeper than the fact that singers I am used to watching master their own material are often singing outside their vocal range with routines they have only had a week to rehearse: I know (rather, I have learned through regimes of race I internalised in 1980s/1990s/2000s Britain) that this "should" not be happening. Not only am I left feeling like Sara Ahmed's "affect alien" - one who refuses to be happy in order to speak "with consciousness of racism" and its histories, but is alienated from the collective by doing so - towards these performances; they even influence the "metanarratives" I form of the performers, built up, as Andrew Goodwin argues, by each viewer's consciousness of stars' performances and public appearances across time. ${ }^{62}$ Renata Sabljak's Dora 1999 entry, with a production that reminds me of Celine Dion's ballads from the mid-1990s, was one of the songs I learned when I first studied Croatian; if it is really true (as I remember reading during my $\mathrm{PhD}$ in one or other newspaper article bemoaning the state of the Croatian music industry) that her first album sold less than a hundred copies, one of them is at my parents' home. And now I cannot hear it without remembering the sight of her impersonating CeeLo Green.

Within the everyday culture of Croatian entertainment, whether TLZP should use blackface has until recently not even been a question. The prosthetics artists behind Sabljak's transformation as Green were proud enough to post behindthe-scenes images on Facebook, asking in Croatian and English: "This Sunday Renata changed color and size. How did you like her transformation to Cee Lo Green?"63 In a trailer from the 2016 season (Jurčević's), showing contestants' prosthetics fittings, the voiceover simply presents skin colour as another characteristic that performers must change along with voice and body shape ("stas"); contestants talk of the challenges of performing across gender boundaries, but not of performing across boundaries of race. ${ }^{64}$ Knowledge of blackface as a racist practice, or even as a practice that could influence viewers' perception of contestants, is, or was then, wholly distant to the milieu in which these digital artefacts circulated and the audiences they were expected to have. Their discussions of cross-gender transformations "know" that norms of movement and appearance are divided by gender in a way they do not "know" that modes of embodying gender are also racialised; and yet the show's performances (of whiteness as much as blackness) are still imbued with "knowledge" about race, or they would not be a spectacle at all.

Whether I am judging Croatian entertainment culture by an unfair foreign standard may be important affectively and analytically - indeed the problem of whether one could legitimately apply critical race lenses to the music and television culture of a nation that did not have the same history of coloniality and racism as the UK helped to motivate my work in Race and the Yugoslav Region - but is of little structural significance to a show aimed at Croatian television viewers. As an unexpected viewer I am admittedly an extreme edge case, as a scholar of the global politics of race who also knows Croatian popular music from the 1990s and 2000s very well. To the extent that viewers in internationally-distributed, socially-engaged fandoms encounter clips from $T L Z P$, however, my viewing position is not wholly unique. Where viewers who understand blackface as racialised and racist encounter Croatian popular music through Eurovision (as I first did) and follow favourite acts on to other television performances including $T L Z P$, in particular, the potential for such a collision has existed for some time. Lane alludes to a similar prospect when remarking that the different prevailing meanings of blackface in Spain and the USA are "a lesson Paz Vega may some time learn the hard way if she achieves celebrity status in the US and this image follows her there."65 In 2020 , this prediction came true when Damir Kedžo (who debuted in 2003 as a finalist of the Story Supernova Music Talents show on Nova TV and became a member of Croatia's first boy band) was chosen to represent Croatia at Eurovision and fans discovered that in the course of TLZP S3 he had impersonated The Weeknd.

\section{Critical Reception of TLZP}

While individual Croatian critics had discussed TLZP's blackface as racist before 2020, these interventions did not seem to reverberate. Tportal's TV critic Zrinka Pavlić attacked TLZP's "sexism, racism, in short - the most ordinary

chauvinism" during its very first series, commenting also on judges' remarks about contestants' rears and "an artist 
impersonating a blind singer as if blind people are retarded [retardirane] and unable to walk"; Facebook users had dismissed objections as "stupid American jokes! To them everything is racism."66 The feminist Barbara Pleić Tomić agreed that blackface in Croatia contained "exceptionally complex layers of racial politics" and suggested, with reference to the Wonder impersonations, that viewers would have found it distasteful to see a similar impersonation of a white Croatian singer who uses a wheelchair, Zdravko Škender. ${ }^{67}$ The portal Index published an article in 2016 that acknowledged Croatia did not have "a tradition of 'minstrel shows' or a history of exploiting and appropriating black culture" but ended by asking readers to reflect on an Afro-Italian woman's comments about blackface on the "much closer to us" Italian edition: "as a black girl who was born and grew up in Italy, this is as disgusting and dehumanising to me as it would be to an African-American. I, like all black people in Italy (yes, we exist) deserve better."68 A poll asking readers whether TLZP's cross-racial imitations were "acceptable or insulting" had 73\% of respondents answer "I don't see the problem. They're just ordinary imitations." I commented on TLZP during an interview with Novosti magazine in 2019 , to apparently no reaction at all. ${ }^{69}$

In late May 2020, however, Kedžo responded on Twitter to Eurovision fans who had supported his entry and engaged with him online during the series of "home concerts" featuring artists from the cancelled 2020 contest, but had been disappointed to find out he had performed in blackface on TLZP. (Besides The Weeknd, he had also impersonated Earth, Wind and Fire, as well as Tina Turner and Mariah Carey using much lighter skin tones.) Though the original messages to Kedžo are no longer accessible, Kedžo's response remained accessible when this article was being drafted in November 2020. Dated three days after the murder of George Floyd, it acknowledged "recent events in the United States" as his reason for speaking out. ${ }^{70}$ Kedžo stated that:

Racism is all around us. Even though l'm born and raised in a society where it's not questioned because my country doesn't have a history of it, we all do it. Unintentionally. And when you start to educate yourself you see that part of you that you never thought about. [...] I'm am honestly from the bottom of my heart sorry that I hurt any of my fellow humans with my black face. I was not aware. ${ }^{71}$

Interestingly, as part of his thread, Kedžo mentioned he had "read an amazing article [a] few days ago, which opened my eyes" by arguing blackface should be recognised as equally tasteless as impersonating a disabled singer in a wheelchair ${ }^{72}$ - maybe even Pleić Tomić's blog post, which had compared blackface to impersonating Zdravko Škender. This encounter and reflection is significant because it occurred through direct interaction with transnational fans through social media, where Eurovision fans enjoy a "celebratory, connected liveness" in the build-up to Eurovision but increasingly also express attachments with anti-racist representational politics: ${ }^{73}$ while Eurovision may often be, as Sieg argues, a site for staging neoliberal fantasies of belonging, and often is, here it also became a site for transversal dialogue. Among the many repercussions of the outbreak of activism and reflection Floyd's murder sparked around the globe, was apparently a Croatian singer reflecting on his performances in blackface on national TV.

With Black Lives Matter protests remaining newsworthy throughout the summer, including some awareness of foreign media organisations' responses, a wider public and media reckoning with TLZP's blackface in Croatia appeared to occur in September 2020 when the show resumed. TLZP 6: 3, Croatia's most viewed programme that day, was broadcast on September 27 with a full half of its transformations involving blackface of various shades (Lana Klingor Mihić as Rihanna, Orsag as Ozuna, Marko Braić as Andre 3000, and Lu Jakelić winning the episode as Ciara). ${ }^{74}$ The tone and volume of critical replies to TLZP's social media posts was sufficient for national news portals to report on them, relaying comments like the following (in Croatian):

When will Croats better understand that this is wrong and directly racist? This is shameful for national TV. In a normal society this wouldn't go unaddressed..$^{75}$

A petition launched that night by Roxanne Flamingo from the (Croatian) House of Flamingo drag collective (a community which, her social media presence hints, does reflect critically about the ethics of cross-racial drag) 
had gathered 935 signatures by the time of writing, with the caption "Let's fight this racist thing and educate the people about it!"76 Speaking to the blogger Marko Petrić, Flamingo emphasised the petition was directed against the practice rather than the show, or the skill of the contestants and make-up artists who worked on it - that is, it came from a position of critical fandom. ${ }^{77}$

Media coverage of the controversy, when it explained why blackface could be considered racist, universally appeared to do so with reference to 19th-century US minstrelsy, such as Index's paragraph that:

Blackface is a term for white people making themselves up as people with dark or black skin. In the 19th century blackface was very popular as a form of burlesque or vaudeville in the USA. White actors would paint their faces and play blacks or, better said, caricatures of blacks, making the audience laugh and spreading racial stereotypes at the same time. ${ }^{78}$

Articles like these implicitly took a similar pedagogical position to Kedžo and Flamingo, suggesting that Croatian society needed to be educated about blackface in order to reach a more advanced, progressive understanding where blackface would be set aside and where, by rejecting racism, Croatian society would simultaneously be demonstrating its modernity. Defences included an Instagram post by the show's singing coach, Martina Tomčić Moškaljov, stating "I find it very interesting that anyone is bothered by the super-talented Lu's fantastic transformation into a singer with dark skin, and no-one is bothered by the mega-talented Fabijan Pavao Medvešek's transformation into a woman with white skin." One article about the post on the gossip website Story (which unlike Index does not have a reputation for cultural critique) ended with an explanation of how blackface derived from a practice which had entertained "white people and slave-owners" and concluded "viewers had sent the message that Croats should be better educated about it."79 Nova TV, for its part, gave a statement which (like its trailers) equated race to all the transformations' other axes of difference and avoided engaging with the power dynamics and histories of racism:

The concept of Tvoje lice zvuči poznato is based on contestants transforming into well-known people from the worldwide and domestic music scene who are treated equally in the choice - independent of sex, age, skin colour and nationality. The candidates' aim is to transform themselves into the artist they are imitating as faithfully as possible - through their appearance, vocals, movement and mimicry. ${ }^{80}$

Absent from this statement is acknowledgement that racism has already stratified how even celebrities are regarded, and whiteness and blackness already exist in an unequal relation.

The underlying theme throughout Croatian critiques of blackface in 2020, the idea that society needs to be "educated" in order to be "normal," represents a refrain of measuring the nation against the benchmark of the West that has characterised the cultural politics of Croatia and other central and south-east European societies ever since the transnational collapse of state socialism (and, indeed, before). ${ }^{81}$ Discourses of the nation needing to "catch up" with the West, especially when Westerners are looking, can be mobilised to support everything from music critics arguing that Croatian pop acts should not try to sound like "Balkan" pop-folk songs to campaigns for Croatia to improve LGBTQ rights. ${ }^{82}$ Sensitivities that the nation is not "normal" and that it must reform to pass muster with the Western norm, accentuated by the fact that central and south-east European nations were under the direct political gaze of the European centre during the EU accession process, are the grand narrative of identity in media cultures on the "semiperiphery" of Europe. ${ }^{83}$ Tactically, this argument is probably a useful tool for persuading a broadcaster in a society aspiring to be seen as modern to continue its successful talent show without blackface, as broadcasters want entertainment programming to appeal to the mass mood. From a structural perspective, nevertheless, the discourse does not take the further step of exposing the persistence of racism in either the contemporary West or Croatia itself (a state where police are now repeatedly accused of employing brutal methods to push undocumented Muslim and African migrants back across the Bosnian border ${ }^{84}$ ) - and paradoxically reinscribes a deeply-seated yet abstract aspect of global raciality, its elevation of the West as the site of modernity above the rest of the globe. 
In an English-language digital public sphere where cross-racial impersonation is highly sensitive, one performance has won surprising acclaim: Tom Holland's performance of Rihanna's "Umbrella" on another celebrity impersonation show, the US edition of Lip Sync Battle in 2017 (3: 16, May 7, 2017). ${ }^{85}$ Widely praised for the skill and confidence with which he embodies a "genuine femininity" rather than the "phony imitation" delivered by most male-to-female celebrity drag (including TLZP's), Holland achieves the impersonation without exaggerating any feminine attributes for comic effect or darkening his skin: and yet it would be hard to call this performance, now viewed more than 63 million times on YouTube, an unfaithful impersonation of Rihanna. ${ }^{86}$ While admittedly YFSF impersonations pose the extra challenge of live singing, usually of lines written for different vocal timbres than one's own, Holland's "Umbrella" still poses the question: if a performer cannot make themselves recognisable as impersonating Rihanna, Beyoncé, Prince, or any other globally iconic star of African descent without resorting to blackface, surely they cannot be doing a very good job?

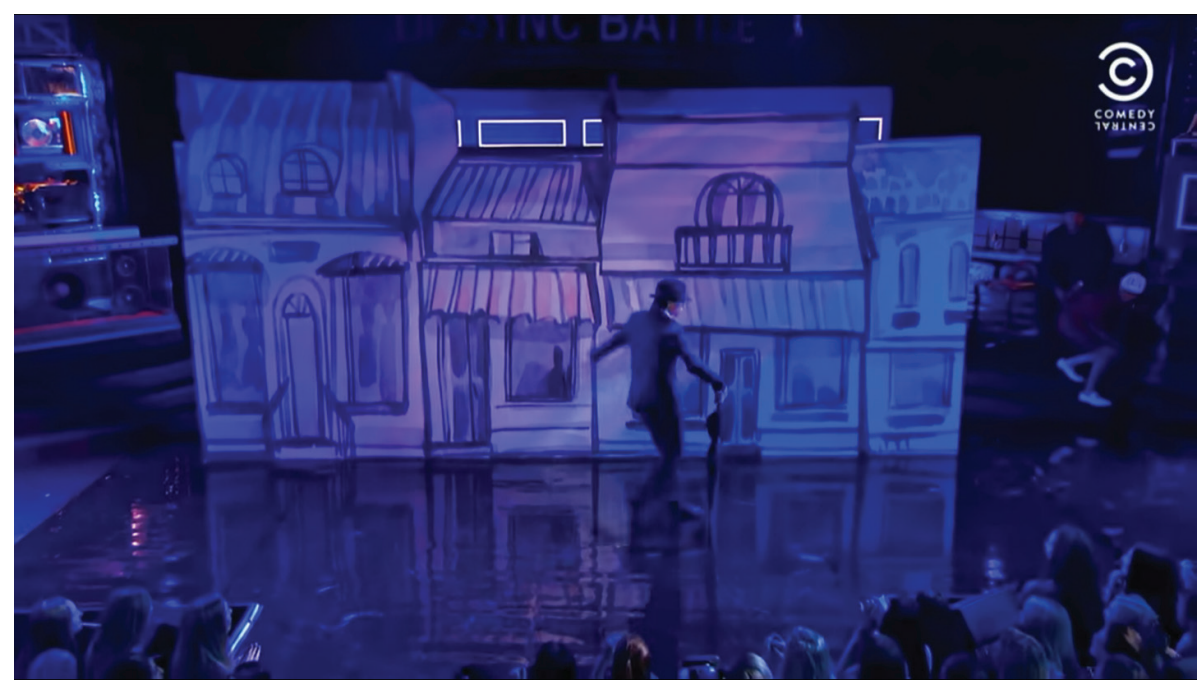

Video 3. Tom Holland, “Umbrella," Lip Sync Battle (Comedy Central, May 7, 2017).

This illustration, though tactically resonant (what performer, about to "go viral," would not rather be winning a reputation like Holland's than Mando's?), still does not answer the contradiction of incommensurability posed by TLZP's blackface and its accidentally-transnational spectatorship. It still sets a white British actor on a US show as a pedagogical example for the many European television markets where blackface is still routine when white performers impersonate stars of African descent. Neither does it address the question of "How did that (performance tradition) get there $[\ldots]$ ?", which Stephen Johnson raises with reference to his own Canadian community but which should equally be asked of translations of blackface beyond societies where the Atlantic slave trade directly took place.$^{87}$ Catherine Cole, who has observed uses of blackface among Black Ghanaian entertainers as well as among young white people in the US, calls for scholars studying blackface's travels around "the circuits of empire" to resist "interpretive imperialism" by recognising that "[o]ften what is being played out through this complex masquerade is a theater of difference that is quite particular, idiosyncratic, and local" instead. ${ }^{88}$ Can blackface in Croatia be written about through a gaze shaped by whiteness and anti-racism in Britain without bringing similar imperialism in train?

The theatre of difference behind how that got there, with blackface impersonation in Croatia, is the product of complex influences. The impersonated stars are part of Croatia's pop canon because of affinities for soul and disco in socialist Yugoslavia which Croats and others could enjoy while priding themselves on living in a society that had not committed the USA's national sin of slavery and racism, and which had allied with global anti-colonialism through the Non-Aligned Movement; the adoption of northern European dance music, often voiced by Afro-Europeans, as a model for a new 
"Western" style of Croatian pop production for a few influential years early in post-Yugoslav Croatia's cultural life; and the global economy of celebrity in which Beyoncé, Rihanna and other stars of African descent are globally recognisable. The convention of wearing dark make-up to play them will have its own antecedents that still deserve to be researched (how common, for instance, was it when comedians played African and Asian characters on Yugoslav television?). The racialisation of humour, and how "Africans" are depicted to Croatian audiences, will likewise stretch back through and past television history into commodity culture and the stage, in a country that until 1918 was part of the Habsburg lands.

Before this work has been done, what answer can we give to whether blackface is still a racialised practice in a country without, as Lane would put it, its "own colonial past"? $?^{89}$ It is, to the extent that Croatia too was part of a globally-translated racialised cultural and intellectual imaginary through commodity culture and scientific racism; through investments in the culture of European colonisation and exploration that some Croatians exercised even though the polity was not sovereign enough to sponsor colonial expeditions or trading companies on its own; and to the extent that the comic elements of cross-racial impersonations align with stereotypes of Black masculinity and Black womanhood legible from other sites of Croatian culture such as jokes and cartoons. Alongside the chief "national racial regimes" that Imre observes in central and eastern European reality television, one "assigned to the Roma to mark the whiteness of nations from the inside" and another "assigned to other, "foreign' racial minorities to safeguard it from the outside," a third is entangled with them - one where comedic transgressive difference embodied by performers from the white majority reasserts their whiteness by showing they know how to impersonate the contents of those other racial regimes. ${ }^{90}$

What prospects might there now be for the attention drawn to blackface on TLZP in 2020 to change cross-racial impersonation practices on Croatian television and possibly elsewhere (not least now it has been shown to risk damaging artists' relationships with international fans, potentially complicating an ambitious broadcaster's future Eurovision entry)? Celebrities and their managers might demand that they not be asked to wear blackface before signing contracts to participate; or alternatively the practice might carry on behind a digital geoblock, where broadcasters and contestants are more protected from scrutiny and embarrassment, though the concealment would need to extend to screenshots and social media feeds to be complete. Kedžo's tweets suggested that impersonated artists, or at least their music publishers, are already aware of how they will be represented ("The responsibility lies in artist[s] who are being impersonated too. They know about it. Because EVERY song is approved by artists publishers") ${ }^{91}$ Informing the publisher might not necessarily inform the artist once they have signed reproduction rights away, so it is still not clear whether a Rihanna or Beyoncé - or a Mel B, impersonated by Matko Knešaurek in TLZP 5: 5 - are aware of or comfortable with these uses of their likeness, or how they could prevent it if they were not. For individuals like Petrić, Flamingo and Kedžo's admiring but critical fans who wish to see TLZP continue without blackface, the space Kedžo may have been able to have to reflect on the practice because he was approached directly by a fan rather than as media scandal may have implications for how we publicise critique.

The course of that critique, too, could be extended beyond the most common move of explaining the US history of racist blackface as the reason why it should not be used in Croatia. How much further could it go, once the research has been done, into increasing public knowledge of histories of blackface and racist representations of Africa in Croatia? If reality television in postsocialist Europe "has both confirmed and unraveled national narratives and selfdefinitions," as Imre argues, TLZP has confirmed a prevailing narrative of Croatia as a nation that is innocent of racism, but could yet unravel one too, if there is willingness to grapple with how a practice Croatian critics acknowledge as linked to racism in the USA has also taken root there. ${ }^{92}$

\section{Notes}

1. See Stijn Reijnders, "Media Rituals and Festive Culture: Imagining the Nation in Dutch Television Entertainment," International Journal of Cultural Studies 10, no. 2 (2007): 225-242.

2. Belén Puebla Martínez, Silvia Magro Vela and Rainer Rubira-García, "Industria televisiva en España: de lo local a lo global y viceversa: Tu cara me sueña como estudio de caso" [The television industry in Spain: from the local to the global and vice versa: Tu cara me sueña as case study], Collección Mundo Digital de Revista Mediterránea de Comunicación 30, (2018). 
3. Jing Jamie Zhao, "A Splendid Chinese Queer TV?: 'Crafting' Non-Normative Masculinities in Formatted Chinese Reality TV Shows," Feminist Media Studies 16, no. 1 (2016): 167.

4. E.g. Ramón Martín-Guart and José Fernández Cavia, "Children in Front of the Television: the Adultisation and Digitisation of Audiovisual Content: a Comparative Analysis According to Age and Gender in Spain,” Prisma Social, no. 1 (2016): 209-237, https://www.redalyc.org/pdf/3537/353747311008.pdf

5. See Ann Fletchall, "US Television Travels Abroad: Global TV and the Formatting Trend," in Mediated Geographies and Geographies of Media, eds. Susan P. Mains, Julie Cupples and Chris Lukinbeal (Dordrecht: Springer, 2015), 111-126.

6. See Ella Shohat and Robert Stam, Race in Translation: Culture Wars Around the Postcolonial Atlantic (Durham, NC: Duke University Press, 2012).

7. See Lisa Nakamura, “'Where Do You Want to Go Today?': Cybernetic Tourism, the Internet, and Transnationality," in The Visual Culture Reader, ed. Nicholas Mirzoeff (2 ${ }^{\text {nd }}$ ed., London: Routledge, 2002), 255.

8. Annabel Tremlett, "Demotic or Demonic?: Race, Class and Gender in 'Gypsy' Reality TV," The Sociological Review 62, no. 2 (2014): 316-334; Anikó Imre, "Love to Hate: National Celebrity and Racial Intimacy on Reality TV in the New Europe," Television and New Media 16, no. 2 (2015): 103-130; Anca Pusca, "Representing Romani Gypsies and Travellers: Performing Identity from Early Photography to Reality Television," International Studies Perspectives 16, no. 3 (2015): $327-344$.

9. Imre, "Love to Hate," 105.

10. Rob Waters, "Black Power on the Telly: America, Television, and Race in 1960s and 1970s Britain," Journal of British Studies 54, no. 4 (2015): 947; see also Sarita Malik, Representing Black Britain: Black and Asian Images on Television (London: Routledge, 2002), 108-122.

11. See, e.g., Lutgard Mutsaers, "Fernando, Filippo, and Milly: Bringing Blackness to the Eurovision Stage," in A Song for Europe: Popular Music and Politics in the Eurovision Song Contest, eds. Ivan Raykoff and Robert Deam Tobin (Aldershot: Ashgate, 2007), 61-70.

12. Kaarina Nikunen, "Difference in Reality: Ethnic Minorities and the Boundaries of the Nation in Reality TV in Finland," Popular Communication 11, no. 4 (2013): 303.

13. Ibid.

14. Ibid.

15. See Anikó Imre, "Whiteness in Post-Socialist Eastern Europe: the Time of the Gypsies, the End of Race," in Postcolonial Whiteness: a Critical Reader on Race and Empire, ed. Alfred J. López (Albany, NY: SUNY Press, 2005), 79-102.

16. Christine Grandy, "The Show is Not About Race': Custom, Screen Culture, and The Black and White Minstrel Show," Journal of British Studies 59, no. 4 (2020): 870.

17. Ibid.: 864

18. Ibid.: 862

19. "Spice Girls Calls Out TV Host for Blackface Stunt (1997)," YouTube, https://www.youtube.com/watch?v=LvqYY9A1I7A

20. Sébastien Chauvin, Yannick Coenders and Timo Koren, "Never Having Been Racist: Explaining the Blackness of Blackface in the Netherlands," Public Culture 30, no. 3 (2018): 509-526.

21. Gloria Wekker, White Innocence: Paradoxes of Colonialism and Race (Durham, NC: Duke University Press, 2016).

22. Ibid., 18.

23. Catherine M. Cole, "American Ghetto Parties and Ghanaian Concert Parties: a Transnational Perspective on Blackface," in Burnt Cork: Traditions and Legacies of Blackface Minstrelsy, ed. Stephen Johnson (Amherst, MA: University of Massachusetts Press, 2012), 238.

24. Jill Lane, "Becoming Chocolate, a Tale of Racial Translation," Theatre Journal 59, no. 3 (2007): 382.

25. Ibid.

26. Ibid.: 385

27. See Catherine Baker, Race and the Yugoslav Region: Postsocialist, Post-Conflict, Postcolonial? (Manchester: Manchester University Press, 2018), including a short discussion of Croatian and Serbian TLZP.

28. Lane, "Becoming Chocolate": 386.

29. Anikó Imre, Katarzyna Marciniak and Áine O’Healy, "Transcultural Mediations and Transnational Politics of Difference," Feminist Media Studies 9, no. 4 (2009): 387

30. Nick Holdsworth, "Endemol Sells New Formats to Central and Eastern Europe," Hollywood Reporter, September 30, 2013, https://www.hollywoodreporter.com/news/endemol-sells-new-formats-central-639085

31. The differences between (mutually-intelligible) Serbian and Croatian do not affect any of the title's words.

32. The US and UK editions, which each only aired for one season in 2014 , were not marked as combining "international" and "local" since their popular music scenes already dominate global pop, though some UK stars were not impersonated on the US show and vice versa.

33. Catherine Baker, "The Politics of Performance: Transnationalism and its Limits in Former Yugoslav Popular Music," Ethnopolitics 5, no. 3 (2006): 275-293.

34. Zala Volčič and Mark Andrejevic, "Commercial Nationalism on Balkan Reality TV," in The Politics of Reality Television: Global Perspectives, eds. Marwan M. Kraidy and Katherine Sender (London and New York: Routledge, 2011), 114-115. 
35. See Vedrana Veličković, "Belated Alliances?: Tracing the Intersections Between Postcolonialism and Postcommunism," Journal of Postcolonial Writing 48, no. 2 (2012): 164-175.

36. TLZPhr Nova TV, "Tvoje lice zvuči poznato - odljevi za maske \Kreće 3. Sezona" [TLZP - make-up fittings - Season 3 is coming], YouTube, August 4, 2016, https://www.youtube.com/watch?v=8dt3QFilxTo

37. Each episodes' transformations are recorded on Wikipedia: "Tvoje lice zvuči poznato (Croatian TV series)," https:// en.wikipedia.org/wiki/Tvoje_lice_zvu\%C4\%8Di_poznato_(Croatian_TV_series), for S1-S5, and "Tvoje lice zvuči poznato 6 (Hrvatska)," https://hr.wikipedia.org/wiki/Tvoje_lice_zvu\%C4\%8Di_poznato_6_(Hrvatska), for the incomplete S6. The total number of impersonations slightly exceeds the total number of performances because a small number of performances have involved two impersonations (the same contestant performing as both partners in a duet).

38. Katrin Sieg, Ethnic Drag: Performing Race, Nation, Sexuality in West Germany (Ann Arbor, MI: University of Michigan Press, 2002), 2.

39. Katrin Sieg, "Wii Are Family: Performing Race in Neo-Liberal Europe," Theatre Research International 38, no. 1 (2013): 22.

40. José Esteban Muñoz, “The White to Be Angry': Vaginal Davis's Terrorist Drag," Social Text, 52-3 (1997): 84, 86.

41. Ludmiła Janion, "The Rise and Fall of the Progressive Drag Queen: Westernization of Cross-Dressing in 1990s Poland," Sexualities 23, no. 7 (2020): 1191.

42. Diane Railton and Paul Watson, Music Video and the Politics of Representation (Edinburgh: Edinburgh University Press, 2011), 109

43. Data source as Table 1.

44. Antena 3, "Tu cara me suena - Santiago Segura imita a Stevie Wonder" [TCMS - Santiago Segura imitates Stevie Wonder], YouTube, November 7, 2013, https://www.youtube.com/watch?v=ulQ4D3-5xc8

45. Tvoje lice zvuči poznato, "Vanda Winter kao Stevie Wonder" [Vanda Winter as Stevie Wonder]: I just called to say I love you, YouTube, December 3, 2015, https://www.youtube.com/watch?v=JenMbJuxm_M

46. Znan obraz ima svoj glas, "Kako se je izkazal Tomaž kot Stevie Wonder?” [How did Tomaž do as Stevie Wonder?], Facebook, April 6, 2014, https://www.facebook.com/ZnanObrazlmaSvojGlas/ photos/a.213831538813566.1073741828.213518925511494/226744144188972/?type=3\&comment_ tracking $=\% 7 \mathrm{~B} \% 22 \operatorname{tn} \% 22 \% 3 \mathrm{~A} \% 22 \mathrm{O} \% 22 \% 7 \mathrm{D}$

47. Karin Stoegner and Ruth Wodak, “'The Men Who Hated Britain': the Discursive Construction of 'National Unity' in the Daily Mail," Critical Discourse Studies 13, no. 2 (2016): 193-209.

48. "This Woman Blacked Up As Stevie Wonder in a TV Talent Show," The Daily Edge, August 2, 2013, https://www. dailyedge.ie/stevie-wonder-talent-blacked-up-1019920-Aug2013/; "Greek Singer Sparks Outrage With Black Face Stevie Wonder Impersonation on Reality TV Show," New York Post, August 2, 2013, https://nypost.com/2013/08/02/ greek-singer-sparks-outrage-with-black-face-stevie-wonder-impersonation-on-reality-tv-show/; Hugo Gye, "Is This The Most Tasteless Talent Show Performance Ever?: Greek Pop Star 'Blacks Up' to Perform as Stevie Wonder," Daily Mail, August 1, 2013, https://www.dailymail.co.uk/news/article-2382432/Greek-pop-star-Mando-blacks-StevieWonder-Your-Face-Sounds-Familiar.html

49. "Edsilia Rombley doet Pink!" [Edsilia Rombley does Pink!], Uitzending.net, December 29, 2012, https://www.uitzending.net/ gemist/158400/RTL-4/Your_Face_Sounds_Familiar.html

50. Ulrike Rohn, "Small Market, Big Format: Idols in Estonia," Baltic Screen Media Review 2, no. 1 (2014): 126-127. Estonia's Idols franchise was taken off air in 2012 so that the production company could instead produce its adaptation of YFSF. The Estonian version too contains cross-racial impersonation in blackface, including the 2012 Estonian Eurovision representative, Ott Lepland, impersonating Bobby McFerrin.

51. Fletchall, "US Television Travels Abroad," 118.

52. See Marko Zubak, “Absolutely Yours': Yugoslav Disco Culture in Late Socialism,” in Made in Yugoslavia: Studies in Popular Music, eds. Danijela Š. Beard and Ljerka V. Rasmussen (London: Routledge, 2020), 89-98.

53. Saidiya V. Hartman, Scenes of Subjection: Terror, Slavery, and Self-Making in Nineteenth Century America (Oxford: Oxford University Press, 1997), 26.

54. TLZPhr Nova TV, "TLZPhr Lana Jurčević kao Boney M” [Lana Jurčević as Boney M], YouTube, October 3, 2016, https://www. youtube.com/watch?v=1_KlivuGKgs

55. adygehayri, "Boney M Daddy cool," YouTube, n.d., https://www.youtube.com/watch?v=QtxICsVKkvY

56. Simon Weaver, "Liquid Racism and the Ambiguity of Ali G," European Journal of Cultural Studies 14, no. 3 (2011): 256.

57. bell hooks, We Real Cool: Black Men and Masculinity (London: Routledge, 2004), 79.

58. Donna A. Buchanan, "'Oh, Those Turks!': Music, Politics, and Interculturality in the Balkans and Beyond," in Balkan Popular Culture and the Ottoman Ecumene: Music, Image, and Regional Political Discourse, ed. Donna A. Buchanan (Lanham, MD: Scarecrow Press, 2007), 62-63.

59. See Judith Halberstam, "Mackdaddy, Superfly, Rapper: Gender, Race, and Masculinity in the Drag King Scene," Social Text 52-3 (1997): 124-128.

60. Kathryn Rosenfeld, "Drag King Magic: Performing/Becoming the Other," Journal of Homosexuality 43, no. 3-4 (2003): 210 (emphasis original). 
61. Apart from briefly mentioning the Greek influences on the sound of one of her songs in a paper about "Balkanness" and the boundaries of Croatian musical identity, I believe this is the first time I have referred to her at all: Catherine Baker, "When Seve Met Bregović: Folklore, Turbofolk and the Boundaries of Croatian Musical Identity," Nationalities Papers 36, no. 4 (2008): 754.

62. Sara Ahmed, The Promise of Happiness (Durham, NC: Duke University Press, 2010), 158; Andrew Goodwin, Dancing in the Distraction Factory: Music Television and Popular Culture (Minneapolis, MN: University of Minnesota Press, 1992 ), 98.

63. DoubleCheck SFX, "Renata je ove nedjelje promijenila i boju i veličinu" [Renata changed both colour and size this Sunday], Facebook, November 22, 2015, https://www.facebook.com/DoubleCheckSFX/ photos/a.1010716058949699/1034881823199789/?type=3\&comment_tracking=\%7B\%22tn $\% 22 \% 3 A \% 220 \% 22 \% 7 D$

64. "Tvoje lice zvuči poznato - odljevi za maske," 1.55

65. Lane, "Becoming Chocolate": 382.

66. Zrinka Pavlić, "Nimalo diskretan šarm seljačkog šovinizma" [The not at all discreet charm of peasant chauvinism], Tportal, December 17, 2014, https://www.tportal.hr/magazin/clanak/nimalo-diskretan-sarm-seljackog-sovinizma-20141203 (emphasis original).

67. Barbara Pleić Tomić, "Blackface u Hrvata" [Blackface among the Croats], Muf, November 11, 2014, https://muf.com. hr/2014/11/11/blackface-u-hrvatal

68. "Tvoje lice zvuči rasistički: što mislite o crnim licima u popularnom showu?" [Your face sounds racist: what do you think about black faces on the popular show?], Index, November 21, 2016, https://www.index.hr/magazin/clanak/tvoje-lice-zvucirasisticki-sto-mislite-o-crnim-licima-u-popularnom-showu/933262.aspx

69. Petar Odak, “Catherine Baker: Dvornikova 'Afrika' sažima kontradiktornu poziciju regije” [Dvornik's 'Afrika' sums up the region's contradictory position], Novosti, April 24, 2019, https://www.portalnovosti.com/catherine-baker-dvornikova-afrika-sazimakontradiktornu-poziciju-regije

70. Damir Kedžo, “Thought about,” Twitter, May 28, 2020, https://twitter.com/DamirKedzo/status/1265962594042556416 [tweet deleted since last accessed]

71. Damir Kedžo, "To conclude this," Twitter, May 28, 2020, https://twitter.com/DamirKedzo/status/1265995768038592512 [tweet deleted since last accessed]

72. Damir Kedžo, "I read an amazing article few days ago, which opened my eyes," Twitter, May 28, 2020, https://twitter.com/ DamirKedzo/status/1265990649985339393 [tweet deleted since last accessed]

73. See Abby Waysdorf, "This is Our Night: Eurovision Again and Liveness Through Archives," in Pandemic Media: Preliminary Notes Towards an Inventory, eds. Laliv Melamed, Philipp Dominik Keidl, Vinzenz Hediger, and Antonio Somaini (Frankfurt: Goethe University Frankfurt, 2020), https://pandemicmedia.meson.press/chapters/activism-sociability/this-is-our-nighteurovision-again-and-liveness-through-archives/; David Smith, "Croatia: "I Am Extremely Sorry from the Bottom of My Heart' - Damir Kedžo Apologises for Blackface Performances," Wiwibloggs, May 28, 2020, https://wiwibloggs. com/2020/05/28/damir-kedzo-apologises-for-blackface-performances/254749/; Costa Christou, "Editorial: BLM and the Eurovision Fandom - Committing to Long-Term Change," ESCXtra, June 17, 2020, https://escxtra.com/2020/06/17/ editorialblm-and-the-eurovision-fandom-committing-to-long-term-change/

74. Klara Rožman, "Rasizam ili transformacija?: fanovi se žestoko bune, a u raspravu se uključila i Martina Tomčić" [Racism or transformation?: fans rise up, and even Martina Tomčić joined the debate], Jutarnji list, September 28, 2020, https://www. jutarnji.hr/kultura/film-i-televizija/rasizam-ili-transformacija-fanovi-se-zestoko-bune-a-u-raspravu-se-ukljucila-imartina-tomcic-15021717

75. “Neke imitacije u TLZP-u razbjesnile ljude: ‘U normalnom društvu ovo ne bi prošlo’” [Some imitations on TLZP angered people: 'In a normal society this wouldn't do'], Index, September 28, 2020, https://www.index.hr/magazin/clanak/gledateljiupozoravaju-tlzp-ovo-je-rasizam-kada-ce-hrvati-shvatiti/2217353.aspx

76. "Remove blackface from Croatian TV," Avaaz, September 27, 2020, https://secure.avaaz.org/community_petitions/en/ nova_tv_remove_blackface_from_croatian_tv/

77. Marko Petrić, "Komentar: tvoje blackface zvuči poznato" [Comment: your blackface sounds familiar],

September 28, 2020, https://markopetric.com/journal/tvoje-blackface-zvuci-poznato-nova-tv [blog deleted since last accessed].

78. "Neke imitacije u TLZP-u."

79. "Martina Tomčić Moškaljov se uključila u raspravu o rasizmu u TLZP" [Martina Tomčić Moškaljov joined the debate about racism on TLZP], Story, September 28, 2020, https://story.hr/Celebrity/a145436/Martina-Tomcic-Moskaljov-se-ukljucila-uraspravu-o-rasizmu-u-TLZP.html

80. Rožman, "Rasizam ili transformacija?"

81. Anikó Imre, Identity Games: Globalization and the Transformation of Media Cultures in the New Europe (Cambridge, MA: MIT Press, 2009), 37.

82. Baker, "When Seve Met Bregović"; Katja Kahlina, "Local Histories, European LGBT Designs: Sexual Citizenship, Nationalism, and 'Europeanisation' in Post-Yugoslav Croatia and Serbia," Women's Studies International Forum 49, (2015): 73-83.

83. See Marina Blagojević, Knowledge Production at the Semiperiphery: a Gender Perspective (Belgrade: Institut za kriminološka i sociološka istraživanja, 2009). 
C. Baker, Your Race Sounds Familiar?

84. Arshad Isakjee, Thom Davies, Jelena Obradović-Wochnik and Karolína Augustová, "Liberal Violence and the Racial Borders of the European Union," Antipode 52, no. 6 (2020): 1762-1768.

85. Comedy Central Latinoamérica, “Lip Sync Battle - Tom Holland," YouTube, July 18, 2017, https://www.youtube.com/ watch?v=jPCJIB1f7jk

86. Kalhari Jayaweera, “Tom Holland's 'Umbrella', Womanhood and Me," Kill Your Darlings, July 8, 2019, https://www. killyourdarlings.com.au/article/tom-hollands-umbrella-womanhood-and-me/

87. Stephen Johnson, "Introduction: the Persistence of Blackface and the Minstrel Tradition," in Burnt Cork, ed. Johnson, 5.

88. Catherine M. Cole, "American Ghetto Parties and Ghanaian Concert Parties: a Transnational Perspective on Blackface," in Burnt Cork, ed. Johnson, 225, 238.

89. See Lane, "Becoming Chocolate," 386.

90. See Imre, "Love to Hate," 105-106.

91. Damir Kedžo, "That being said," Twitter, May 28, 2020, https://twitter.com/DamirKedzo/status/1265986918476627968 [tweet deleted since last accessed].

92. Imre, "Love to Hate," 105.

\section{Biography}

Catherine Baker is Senior Lecturer in 20th Century History at the University of Hull. She began her career researching popular music and narratives of national identity in post-Yugoslav Croatia, and now specialises in the transnational politics of popular culture, media and nationalism, and south-east Europe's relationship to the global politics of race. Her books include Sounds of the Borderland: Popular Music, War and Nationalism in Croatia since 1991 (2010) and Race and the Yugoslav Region: Postsocialist, Post-Conflict, Postcolonial? (2018), and her articles have appeared in European Journal of International Relations, International Feminist Journal of Politics and elsewhere. 